\title{
KADAR PROTEIN BAKSO DAGING AYAM BROILER DENGAN PENAMBAHAN JAMUR TIRAM
}

\author{
Susi Susanti ${ }^{1}$, Ria Harmayani ${ }^{2 *}$ \\ ${ }^{1,2}$ Program Studi Peternakan, Fakultas Peternakan, Universitas Nahdlatul Wathan Mataram, Mataram, Indonesia \\ *Email korespondens : riaharmayani@gmail.com
}

Diterima: 12 Januari 2021. Disetujui: 21 Maret 2021. Dipublikasikan: 26 April 2021

\begin{abstract}
ABSTRAK
Penelitian eksperimental untuk mengetahui kandungan protein bakso daging ayam broiler dengan jamur tiram (Pleurotus ostreatus) dilaksanakan selama 2 bulan dari bulan September-Oktober 2020. Penelitian dibagi menjadi dua tahapan penelitian yaitu tahap persiapan dan tahap penelitian. Tahap persiapan yaitu membuat adonan bakso daging ayam broiler dengan 4 level penambahan jamur tiram yang dilaksanakan di Laboratorium Fakultas Peternakan UNW Mataram. Tahap penelitian yaitu menganalisa kadar protein dari sampel bakso daging ayam broiler berdasarkan AOAC (2005) di Laboratorium INMT Universitas Mataram. Rancangan percobaan yaitu rancangan acak lengkap (RAL) terdiri dari 4 perlakuan yaitu penambahan jamur tiram pada pembuatan bakso, yaitu $0 \%(\mathrm{P} 0), 10 \%(\mathrm{P} 1), 20 \%(\mathrm{P} 2)$ dan $30 \%(\mathrm{P} 3)$ dari berat daging ayam broiler dan 3 kali ulangan. Variabel yang diukur adalah kadar protein bakso daging ayam broiler. Data yang diperoleh dianalisis menggunakan analisa sidik ragam dan uji lanjut dengan BNT. Hasil penelitian menunjukkan bahwa penambahan jamur tiram pada bakso daging ayam broiler berpengaruh nyata $(\mathrm{P}>0,05)$ terhadap kadar protein bakso. Penambahan jamur tiram (Pleurotus ostreatus) bebanding terbalik dengan kadar protein bakso daging ayam broiler. Kadar protein tertinggi (5,37\%) pada bakso daging ayam broiler dengan penambahan jamur tiram terdapat pada penambahan jamur tiram sebanyak $10 \%$ dari berat daging ayam broiler.
\end{abstract}

Kata kunci : Bakso, Daging ayam broiler, Jamur tiram, Kadar protein.

\begin{abstract}
Experimental research to determine broiler chicken meatballs' protein content with oyster mushrooms was carried out for two months, from September to October 2020. The study was divided into two stages, namely the preparation stage and the research stage. The preparation stage was making meatball dough with four levels of adding oyster mushrooms which were carried out in the Animal Science Laboratory of UNW Mataram. The research stage was to analyze the protein content of meatball samples in INMT Laboratory of UNRAM. The research stage was to analyze the protein based on AOAC (2005). The experimental design, namely CRD, consisted of four treatments: the addition of oyster mushrooms from the weight of broiler meats and three replications. The variable measured was the protein content of the meatball. The data obtained were analyzed using ANOVA and LSD test. The results showed that oyster mushrooms to broiler chicken meatballs had a significant effect on protein content. The addition of oyster mushrooms (Pleurotus ostreatus) is inversely proportional to broiler chicken meatballs' protein content. The highest protein content (5.37\%) on broiler chicken meatballs with the addition of oyster mushrooms there is an addition of oyster mushrooms as much as $10 \%$ of the weight of broiler chicken meat.
\end{abstract}

Keywords: Broiler's chicken, Meatball, Oyster mushroom, Protein content.

\section{PENDAHULUAN}

Konsumsi daging nasional hingga saat ini masih tergolong rendah. Rendahnya jumlah konsumsi disebabkan harga sumber protein yang relatif mahal dan terbatas (Situmorang, 2008). Pilihan protein hewani asal daging sangat bervariasi. Sumber protein asal daging salah satunya berasal dari daging ayam. Daging ayam dikenal memiliki kandungan gizi yang cukup baik karena mengandung protein, air, mineral dan vitamin yang dibutuhkan oleh tubuh. Daging ayam broiler adalah daging dari ayam tipe pedaging dengan timbunan daging yang banyak dan biasanya dipanen/ dijual dengan bobot badan rata-rata 1,4 $\mathrm{kg}$ /ekor (Rasyaf, 1992). Kandungan gizi dalam 100 gram dagingnya yaitu 23,6\% protein, 7\% lemak, 62 mg/100g kolesterol, dan $135 \mathrm{Kkal} / 100 \mathrm{~g}$ kalori (Anggorodi, 1994), serta rasa dan aroma yang enak. Nilai manfaat daging ayam meningkat dengan pengolahan, membuat kornet, sosis, dendeng, abon, nugget dan bakso, namun prosesnya dapat meningkatkan dan menurunkan nilai gizi protein olahannya (Soeparno, 2004).

Bakso adalah salah satu olahan daging. Bakso adalah olahan daging yang terbuat dari campuran daging sapi giling dan tepung tapioka, namun variasi daging berasal dari daging ayam, ikan, atau udang bahkan daging kerbau, biasanya disajikan dalam keadaan panas (Wibowo, 1999; Ngadiwaluyo dan 
Suharjito, 2003; Astuti, 1983; Lestari, 1991; BSN, 2004). Kreasi dan formulasi adonan bakso bervariasi. Salah satunya dengan penambahan jamur tiram. Jamur tiram merupakan jamur yang paling banyak dibudidayakan, sehingga mudah diperoleh di pasar tradisional maupun di pasar modern. Jamur tiram memiliki protein rata-rata 3,5-4\% dari berat basah, sedangkan berdasarkan berat kering mengandung 19$35 \%$ protein, $72 \%$ lemak tidak jenuh dan $28 \%$ asam lemak jenuh. Kandungan zat gizi yang dikandungnya berfungsi untuk mencegah kekurangan gizi dan sumber zat besi (Alda, dkk., 2001; Sumarmi, 2006; Ditjen Holtikultura, 2006). Selain bergizi, jamur tiram juga memiliki citarasa yang gurih, sedap dan lezat (Tjokrokusumo, 2008).

Penelitian bakso saat ini diperlukan bertujuan untuk menghasilkan bakso enak, bergizi dengan bahan yang mudah diperoleh serta harga yang ekonomis sehingga penelitian ini menghasilkan luaran formulasi bakso ekonomis yang dapat direkomendasikan secara umum untuk masyarakat luas dan secara khusus bagi produsen bakso.

\section{METODE PENELITIAN}

\section{Tempat dan Waktu Penelitian}

Penelitian dilaksanakan di Laboratorium Fakultas Peternakan Universitas Nahdlatul Wathan Mataram dan Laboratorium Ilmu Nutrisi dan Makanan Ternak Fakultas Peternakan Universitas Mataram selama 2 bulan yaitu pada bulan September-Oktober 2020.

\section{Bahan dan Alat Penelitian}

Bahan yang digunakan dalam penelitian ini terdiri atas bahan utama dan bahan pendukung. Bahan utama adalah daging ayam broiler dan jamur tiram. Bahan pendukung adalah tepung tapioka, tepung terigu, bumbu, air dan es batu yang diperoleh dari pasar tradisional Kebon Roek Ampenan Mataram, serta bahan-bahan kimia untuk analisa protein.

Peralatan yang digunakan untuk pengolahan bakso adalah timbangan, alat penggiling daging, kompor, panci, pisau, baskom dan sendok dan seperangkat alat analisa protein.

\section{Tahap Persiapan Penelitian}

\section{Cara Membuat Bakso}

Daging ayam dan jamur tiram dipotong-potong dengan menggunakan pisau kemudian dimasukan ke alat penggiling hingga halus. Daging yang sudah halus dipindahkan ke mesin pencampur dan memasukan tepung terigu dan tapioka sedikit demi sediktit serta bumbu yang sudah disiapkan. Begitu juga es batu ditambahkan sedikit demi sedikit sampai adonan homogen dan mudah dibentuk. Penambahan jamur tiram dilakukan dalam keadaan segar sebanyak empat level perlakuan berbeda yaitu $0 \%, 10 \%, 20 \%$ dan $30 \%$ dari berat daging.

\section{Membentuk Adonan Bakso}

Pembentukan adonan menggunakan tangan yaitu dengan mengambil segenggam adonan, remas dan tekan ke arah ibu jari. Ukuran bakso yang dibentuk bulatan berdiameter dua sampai tiga sentimeter. Adonan yang sudah dibentuk langsug direbus atau dimasukan ke dalam air mendidih hingga matang. Proses perebusan bakso biasanya berlangsung 10 sampai 15 menit. Bakso akan mengapung dipermukaan air, diangkat, ditiriskan dan didinginkan pada suhu ruang. 
AGRIPTEK : Jurnal Agribisnis dan Peternakan

Vol. 1 No.1, April $2021: 7-11$

Tabel 1. Formulasi Bakso Daging Ayam Broiler dengan Penambahan Jamur Tiram

\begin{tabular}{ccccc}
\hline \multirow{2}{*}{ Bahan (gram) } & P0 $=\mathbf{0} \%$ & \multicolumn{2}{c}{ Level Penambahan Jamur Tiram } \\
& $\mathbf{P 1 = 1 0 \%}$ & $\mathbf{P 2 = 2 0 \%}$ & P3=30\% \\
\hline Jamur Tiram & 0 & 50 & 100 & 150 \\
Daging Ayam & 500 & 500 & 500 & 500 \\
Tepung Terigu & 500 & 500 & 500 & 500 \\
Tepung Tapioka & 500 & 500 & 500 & 500 \\
Es Batu & 100 & 100 & 100 & 100 \\
Bumbu & 30 & 30 & 30 & 30 \\
Air & 100 & 100 & 100 & 100 \\
\hline
\end{tabular}

Sumber: Data Primer Diolah (2020).

\section{Tahap Penelitian}

Kegiatan yang dilakukan dalam tahap penelitian adalah menganalisa sampel kadar protein bakso daging ayam broiler dan jamur tiram dengan metode analisa protein berdasarkan AOAC (2005).

\section{Jenis Penelitian}

Penelitian ini adalah penelitian kuantitatif dengan metode eksperimental yang digunakan untuk mencari pengaruh perlakuan terhadap penambahan level jamur tiram pada bakso daging ayam broiler.

\section{Rancangan Percobaan}

Rancangan percobaan yang dilakukan dalam penelitian ini adalah Rancangan Acak Lengkap (RAL) dengan 3 kali ulangan. Perlakauan berupa penambahan jamur tiram pada bakso daging ayam broiler terdiri atas empat level perlakuan yaitu:

$$
\begin{array}{ll}
\text { P0 } & =(\text { Daging Ayam broiler }+0 \% \text { Jamur Tiram }) \\
\text { P1 } & =(\text { Daging ayam broiler }+10 \% \text { Jamur Tiram }) \\
\text { P2 } & =(\text { Daging Ayam broiler }+20 \% \text { Jamur Tiram }) \\
\text { P3 } & =(\text { Daging Ayam broiler }+30 \% \text { Jamur Tiram })
\end{array}
$$

\section{Analisis Data}

Analisis data menggunakan Rancangan Acak Lengkap (RAL) pola searah adalah sebagai berikut :

Keterangan :

$$
\mathrm{Yij}=\mu+\mathrm{ai}+\varepsilon \mathrm{ij}
$$

Yij = Nilai pengamatan dari perlakuan ke-i ulangan ke-j

$\mu \quad=$ Nilai tengah umum

$\mathrm{T}_{\mathrm{i}} \quad=$ Pengaruh perlakuan ke- $\mathrm{i}$

cij = Kesalahan (galat) percobaan pada perlakuan $\mathrm{ke}-\mathrm{i}$ dan ulangsn $\mathrm{ke}-\mathrm{j}$

Data dianalisis dengan menggunakan Anaisis Sidik Ragam atau Analysis of Variance (ANOVA). Bila anlisis sidik ragam menunjukan perbedaan yang nyata pada perlakuan, maka dilanjutkan dengan uji Beda Nyata Terkecil (BNT).

\section{HASIL DAN PEMBAHASAN}

Nilai protein bakso dipengaruhi oleh kadar protein komposisi bahan penyusunnya. Untuk mendapatkan hasil bakso dengan protein tinggi dan berkualitas harus menggunakan bahan penyusun yang tepat dan dagingnya berkualitas baik dan segar. 
Tabel 2. Rerata Nilai Kadar Protein Bakso Daging Ayam Dengan Level Penambahan Jamur Tiram $0,10,20$ dan $30 \%$.

\begin{tabular}{cc}
\hline Penambahan Jamur Tiram & Kadar Protein Bakso (\%) \\
P0 (Penambahan 0\% jamur tiram) & $4,79 \pm 0,17 * *$ \\
P1 (Penambahan 10\% jamur tiram) & $5,37^{* *} \pm 0,13$ \\
P2 (Penambahan 20\% jamur tiram) & $4,08^{*} \pm 0,00$ \\
P3 (Penambahan 30\% jamur tiram) & $3,88^{*} \pm 0,08$ \\
\hline
\end{tabular}

Sumber: Data Primer Diolah (2020)

Keterangan: Angka yang diikuti superskrip yang sama pada kolom rataan menunjukkan berbeda nyata $(\mathrm{P}>0,05)$, sedangkan angka yang diikuti superskrip berbeda pada kolom rataan menunjukan berbeda sangat nyata $(\mathrm{P}>0,01)$.

Mutu suatu produk pangan yang berasal dari daging ditentukan oleh kadar proteinnya (Winarno, 2004). Pada bakso, penyuplai protein terbanyak dalam adalah daging, sehingga kandungan protein bakso sangat ditentukan oleh jenis dan jumlah daging yang digunakan sebagai bahan baku utama. Berdasarkan uji statistik anova, kadar protein bakso daging ayam broiler yang ditambahkan jamur tiram bervariasi yaitu 3,88-5,37\%. Kadar protein tertinggi terdapat pada P1 (penambahan 10\% jamur tiram). Tabel 2 menunjukkan bahwa penambahan jamur tiram pada bakso daging ayam broiler berpengaruh nyata terhadap kadar protein bakso. Hasil penelitian menggambarkan bahwa semakin banyak jumlah jamur tiram yang ditambahkan maka kadar protein bakso semakin menurun. Hal ini dapat disebabkan oleh kadar protein bakso yang dipengaruhi oleh pemanasan pada saat proses pembuatan bakso. Selain itu, nilai kadar protein berasal dari sumber proteinnya yaitu daging ayam, sementara jamur tiram yang ditambahkan memiliki kadar protein yang lebih rendah daripada protein daging ayam, sehingga dapat menurunkan kadar protein dalam bakso.

Penurunan kadar protein bakso yang ditambahkan jamur tiram juga disebabkan oleh jumlah protein globular semakin banyak karena seluruh protein daging seperti sarkoplasma dan miofibril berbentuk globular (Davideck, et. al, 1990) dan Muchtadi (1990) protein jamur tiram putih juga berbentuk globular yaitu protein berbentuk bola, berisfat larut pada larutan garam dan larutan asam encer, selain itu juga mudah terdenaturasi oleh pengaruh suhu, konsentrasi garam, pelarut asam dan basa (Winarno, 2004).

\section{KESIMPULAN DAN SARAN}

Berdasarkan hasil penelitian dapat disimpulkan bahwa penambahan jamur tiram pada bakso daging ayam broiler berpengaruh nyata terhadap kadar protein bakso. Semakin banyak penambahan jamur tiram (Pleurotus ostreatus) maka kadar protein bakso daging ayam broiler semakin menurun. Kadar protein bakso daging ayam broiler dengan penambahan jamur tiram tertinggi sebesar 5,37\% yaitu pada penambahan jamur tiram sebanyak $10 \%$ dari berat daging ayam broiler.

\section{DAFTAR PUSTAKA}

Alda, E.R., D.R. Permana dan T. Pasaribu. 2001. Aneka Jamur Unggulan yang Menembus Pasar. Grasindo. Jakarta.

Anggorodi. R. 1994. Ilmu Makanan Ternak Umum. PT. Gramedia. Jakarta.

AOAC (Association of Official Analytical Chemist). 2005. Official Method ofAnalysis of The Association of Official Analytical of Chemist. Arlington, Virginia. USA: Association of Official Analytical Chemist, Inc.

Astuti, E. 1983. Pengolahan Daging Curing Sosis dan Bakso di PT. Tirta Rama Unit Badranaya. Laporan Praktek Kerja Lapangan. Fakultas Teknologi Pertanian. Universitas Gadjah Mada. Yogyakarta.

Davideck, J., J. Valisek and J.Pokorny. 1990. Chemical Changes during Food Processing. Elsiver, Amsterdam. 
AGRIPTEK : Jurnal Agribisnis dan Peternakan

Vol. 1 No.1, April 2021 : 7-11

Dirjen Hotikultura. 2006. Jamur Tiram. Deptan RI.

Lestari, S. 1991. Bisnis Bakso Yang Menguntungkan. Media Peternakan DKI

Muchtadi, T.R. 1990. Teknologi Pengawetan Jamur Mutiara (Pleuratus Ostreatus) Laporan Penelitian. Fakultas Teknologi Pertanian. Insitut Pertanian Bogor, Bogor.

Ngadiwaluyo, S. dan Suharjito. 2003. Pengaruh Penggunaan Sodium Tripolyphosfat Terhadap Daya Simpan Bakso Sapi Dalam Berbagai Suhu Penyimpanan. Jakarta.

Rasyaf, M. 1992. Memelihara Ayam Buras. Kanisius. Yogyakarta.

Situmorang, Erikson N, 2008. Pengawetan Daging Ayam (Gallus Gallus domesticus) dengan Larutan Garam Dingin. Fakultas Pertanian Universitas Sumatera Utara:Medan.

Soeparno. 2004. Ilmu dan Teknologi Daging. UGM-Press:Yogyakarta.

Sumarmi. 2006. Botani dan Tinjauan Gizi Jamur Tiram Putih. Jurnal Inovasi Pertanian Vol. 4, No. 2 , 2006.

Tjokrokusumo, D. 2008. Jamur Tiram Putih (Pleurotus ostreatus) Untuk Meningkatkan Ketahanan Pangan dan Rehabilitasi Pangan. Jurnal M. Tek. Ling 4 (1).

Wibowo, S. 1999. Pembuatan Bakso Ikan dan Bakso Daging. Penebar Swadaya.Jakarta.

Winarno, F.G. 2004. Kimia Pangan dan Gizi. PT Gramedia Pustaka Utama. Jakarta. 